IdeAs

Idées d'Amériques

$14 \mid 2019$

Populismes dans les Amériques

\title{
Are Trade Unions and Their Members "Populist"?
}

Les syndicats et leurs membres sont-ils " populistes"?

¿Son los sindicatos y sus miembros "populistas"?

\section{Nelson Lichtenstein}

\section{OpenEdition}

\section{Journals}

Electronic version

URL: http://journals.openedition.org/ideas/6089

DOI: $10.4000 /$ ideas.6089

ISSN: 1950-5701

\section{Publisher}

Institut des Amériques

Electronic reference

Nelson Lichtenstein, « Are Trade Unions and Their Members "Populist"? », IdeAs [Online], 14 | 2019,

Online since 01 October 2019, connection on 08 November 2019. URL : http://

journals.openedition.org/ideas/6089; DOI : 10.4000/ideas.6089

This text was automatically generated on 8 November 2019 .

\section{(c) (i) $\odot$}

IdeAs - Idées d'Amériques est mis à disposition selon les termes de la licence Creative Commons

Attribution - Pas d'Utilisation Commerciale - Pas de Modification 4.0 International. 


\title{
Are Trade Unions and Their Members "Populist"?
}

\author{
Les syndicats et leurs membres sont-ils "populistes"? \\ ¿Son los sindicatos y sus miembros "populistas"?
}

\section{Nelson Lichtenstein}

1 Early in the second decade of the 21st century, shortly after the emergence of the Tea Party phenomenon but just before the Occupy Wall Street movement, hundreds of blue-collar workers, mainly white, mainly male, mostly small-town, and all very angry, had a dramatic standoff with two of the biggest and most aggressive foreign-owned corporations on the planet. The workers were defending a multigenerational way of life that was threatened by a pair of global corporations intent on slashing wages, cutting pensions, and turning a set of skilled occupations into something far more tenuous and contingent.

2 In Longview, Washington, hundreds of workers blocked train tracks and stormed portside loading docks to keep EGT, an East Asian logistics consortium, from outsourcing their jobs to a cheaper set of workers made desperate by a Pacific Northwest economy that had bled logging, manufacturing, and transport jobs for a generation. Until the police stopped their rampage, they used baseball bats to smash windows, damage rail cars, and dump tons of grain onto the ground. More than a dozen were arrested (Greenhouse S., 2011: B2). Meanwhile in Boron, California, deep in the heart of conservative Kern County, scores of beefy miners confronted Rico Tinto, a giant British-Australian combine that was determined to slash labor costs in a small, isolated Mojave Desert town where open pit mining of "Twenty Mule Team Borax" fame was the only game in town. "We're standing up for our community and for every working family in America," was the way most these heavy equipment operators saw their fight ${ }^{1}$.

3 Angry white male workers fearful for their jobs; small towns turned upside down by global economic forces. Surely all this proved a breeding ground for populist resentment, xenophobic outrage, and blue-collar support for the kind of political 
tribune who could promise to "Make America Great Again." And indeed, both of these protests took place in "red" counties that would later vote heavily for Donald Trump in the 2016 elections. ${ }^{2}$

But no. These blue-collar men, and a few women, were all members of the International Longshore and Warehouse Union, a West Coast labor organization that would endorse Bernie Sanders in the 2016 Democratic primaries. No reporter or pundit thought to label these strikers "populist" even at the very height of their confrontation with multinational capital, which took place in 2010 and 2011 when Tea Party outrage was on the upswing. They were unionists and militants who had the moral and financial support of the rest of the labor movement. They confronted a set of corporate opponents in a highly programmatic fashion. They were not alienated, but found solidarity and friendship in their struggle.

5 The same was true of the upsurges that swept several red states in 2018 when school teachers stopped work and descended upon the state capitals in West Virginia, Oklahoma, and Arizona, even as smaller protests stirred the political waters in Kentucky, North Carolina, and Colorado. While these strikes were non-violent and heavily female in composition, they were hardly genteel. Almost all were "a brazen act of mass civil disobedience," because red state politicians had made such public employee work stoppages illegal (Bryant J. 2018; Blanc E., 2019). These protests, all of which demanded higher taxes on the corporations and the rich to channel more money for the public schools, were climaxed by the massive, community-backed Los Angeles teacher's strike of January 2019 which directed much anger at the billionaire philanthropists and financiers who backed an expansion of charter schools, fought unionization in public education and elsewhere, and had poured millions into California school board races to boost candidates with similar ideas (Lichtenstein N., 2018; Sonti S., 2019).

6 To call these strikers, blue-collar or white, populists is to saddle them with a label that does grave injustice. This essay argues that trade unionism in the United States constitutes a very different phenomenon from the social and political movements we today call "populist." Although their demographic composition is often similar, labor organizations emphasize social solidarity, programmatic coherence, and organizational longevity. In contrast, the contemporary populist insurgencies of our era, both left and right, are far more episodic in their appearance, are composed of individuals often alienated and atomistic in their approach to politics, and leave behind few institutions capable of functioning on a permanent basis after the fervor of the campaign season fades away.

7 Contemporary confusion over the meaning of the populist idea therefore reflects a failure of analytic observation. To most pundits and politicians deployment of the term "populist" has become highly problematic because it has become a default phase for various forms of social or political insurgency, with an ideological content that too often lies in the eye of the beholder. As John Judis put it in a recent intervention, "As with ordinary language, even more so with ordinary political language, the different people and parties called "populist" enjoy family resemblances of one to the other, but not a set of traits can be found exclusively in all of them" (Judis J., 2016: 13-14).

8 This was not always so. In the 1890s when the Populist Party rose to prominence in the U.S., these workers, farmers, and radical intellectuals put forward a coherent and farreaching program that echoed down the 20th century decades. The Populists wanted 
electoral reforms to squeeze corruption out of politics, pushed for progressive taxation of income, demanded public control of banking, railroads, and utilities, favored silver over gold in order to expand and cheapen credit, and fought for more public schools and colleges. They were not hayseeds. Nor were they remembered as such. In 1962 for example, the New York Times headlined a liberal congressional effort to defeat A.T.\& T. and keep satellite communications in public hands. "Space Age Populists: Senate Test Today on Satellite Bill Recalls Political Fires of the 1890s." (Philipps C., 1962). In this anti-monopoly effort, contemporary progressives saw the Populists as part of a long and respectable lineage stretching back to the Jacksonians, the Mugwumps, the Progressives, the New Dealers, and the Paul Douglas/Wayne Morse/Estes Kefauver liberals of the 1950s.

9 Populism got a sour, illiberal rewrite when postwar intellectuals like Richard Hofstadter, Seymour Martin Lipset, and Daniel Bell entered the historical and sociological fray. As part of the generation who had witnessed the rise of Stalin and Hitler, these ex-radicals thought they saw in the mass following of Joe McCarthy the kind of authoritarian mobilization that had led to catastrophe in Europe and elsewhere. Since McCarthy came from Wisconsin, and made a regular habit of denouncing Washington civil servants, liberal academics, and moderate Republicans, Hofstadter et al. explained McCarthyism as a kind of revolt against modernity, a pseudoconservatism that traced its roots back to a Populist movement seeking to recapture an agrarian and small town past forever lost in the 20th century. In this reading of their history, Populist mythology celebrated virtuous farmers at the expense of urban sophisticates, found financial conspiracies responsible for the business cycle, and traded in anti-Semitic stereotypes and innuendo (Bell D., 1964; Hofstadter R., 1955, 1963).

10 But Hofstadter and the rest of the New York intellectuals were wrong about the original Populists. As early as 1963 historian Walter Nugent published a refutation, The Tolerant Populists: Kansas Populism and Nativism, an assessment sustained by scores of other historians, including Charles Postel, whose The Populist Vision won the Bancroft Prize in 2008. Meanwhile, in 1967 political scientist Michael Rogin demolished the idea of a generational or demographic linkage between the Populists, illiberal or otherwise, and the followers of Joe McCarthy. In his The Intellectuals and McCarthy: The Radical Specter, Rogin found that the McCarthyites in the 1950s Midwest were far more closely associated with traditional Republican conservatism than with any authoritarianism arising out of plebian angst (Nugent W., 1963; Postel C., 2007; Rogin M., 1967).

But none of this scholarship could dent the evocative framing that took hold in the 1960s and after. The actual Populists of the 1890s, with their well-defined program, their own political party, their affinity for organized labor, and their rootedness in clearly-defined communities, has been forgotten except by academic specialists. Instead, the word populist, following from the work of Bell, Lipset, and Hofstadter, has been applied toward those movements that have arisen as an unstable, often irrational hostility toward an ill-defined elite. George Wallace seemed an early embodiment of the kind of demagogic candidates for high office who took advantage of this strain in American politics (Kazin M., 1995 : 221-244). Over the next half century the populist moniker became a shape shifting category, often an explanatory phrase deployed by journalists to describe the appeal and the following of almost any rightwing politician defaming liberal elites, but also applied at various times to those on the left who 
supported Jimmy Carter, Jim Hightower, Jerry Brown, and Howard Dean. And the Texas billionaire Ross Perot had the populist label applied to him as well (Denison D., 1992).

To the extent that there is a cultural or educational elite, populists resent them; indeed, all those of a cosmopolitan, bi-coastal outlook, notwithstanding the many conservatives who also fill this sociocultural niche. But even more important than the cultural posture or economic program held by those labeled contemporary populists, is another feature of their politics: the atomization and anti-institutionalism of their struggle, a condition that sometimes applies as much to those on the left as on the right. Almost by definition, populists are unorganized in any meaningful sense. They do not function through and with an institution, except perhaps via intense engagement in partisan politics at the height of the campaign season. Mass rallies offer an emotive substitute for substantive political organization and engagement. This kind of populism is therefore the label attached to protest sentiment unmoored by institutional loyalties (Goldberg J., 2015; Bonikowski B., and Gidron N., 2016) . And such populism is by common if unstated agreement, exclusively white. Thus, on the left, neither Black Lives Matter nor the Latino protests of a few years ago, "A Day Without Immigrants" are thought to be populist, while Occupy Wall Street and the Bernie Sanders campaign, both predominately white, are offered this label. On the Right, virtually all political activity is white. But significantly, neither the hyper-organized National Rifle Association, nor the equally well-structured Focus on the Family and the more politically active evangelical churches are normally - or rightfully - thought to be "populist."

13 Jan-Werner Muller, one of the foremost students of modern populism, argues that a criticism of elites, global or local, is not the defining feature of the populism that has swept Europe and North America in recent years. Such a critique has been part of democratic discourse for centuries. Rather Muller argues, populists are distinctive and dangerous - because the crucial feature of modern populism is that those who see themselves as part of this movement claim that they - and only they - represent "the real people," aka the "silent majority," or a volk whose authenticity is defined in barely veiled racial or ethnic terms. What matters about populism is its moralistic antipluralism, writes Muller, because such a posture excludes from the definition of "the real people" a set of marginalized others toward which anger and distain are directed (Muller J.-W., 2018 : 196-197). To Muller "populists portray their political competitors as part of the immoral, corrupt elite," which he claims is "another way of saying that populism is always a form of identity politics" (Muller J.-W., 2017: 3)."

Muller, who has long focused his scholarship on central Europe, is properly sensitive to the authoritarian and anti-democratic character of a mass movement that seeks to demonize its opponents. Such hostility to political and cultural pluralism has generated historical catastrophes well known to the 20th century. But anti-elitism does not have to be culturally or ideologically authoritarian nor does identity politics always have negative consequences. Socialism's animating character, likewise that of militant trade unionism, has been the identification of and contestation with an economic and political elite whose immorality is juxtaposed to that of the virtuous and industrious mass below. As one stanza of "Solidarity Forever," the union anthem puts it:

All the world that's owned by idle drones is ours and ours alone.

We have laid the wide foundations; built it skyward stone by stone. 
It is ours, not to slave in, but to master and to own.

While the union makes us strong. ${ }^{3}$

The key issue here is not labor's moralism, but rather its organizational form and ethos. It is the union, not the charismatic leader, that "makes us strong." And despite the routine demagoguery that labels trade union leaders as "bosses," the fact is that unions are one of the more democratic institutions in American society, certainly more so than the modern political campaign, which has become a form of entrepreneurial selfadvancement, displacing the political party, and then dismantling itself immediately after an election once its capacity to generate money, mobilize partisans, and evoke the imagery of a social movement is no longer needed. Indeed, this was the fate of two of the most inspiring and successful campaigns of recent years. Despite all the plans and determination to build a post-election infrastructure, neither the campaigns of obama in 2008 nor Sanders in 2016 were able to sustain much of an organization independent of the candidate and viable in its own right (Brown D., 2012: 16; Dovere E.-I, 2018).

With all this in mind, let's return to those labor protests for a moment. At Longview and Boron, the striking workers were organized, not merely in a legal or economic sense, but on a trajectory that extended from the social and ideological to the profoundly emotive and personal. Although in each case a powerful corporation was the aggressor, the workers were not mere victims, but combatants, empowered by their friendships, their local union, the larger ILWU, and supporters across the country and even abroad. Rico Tinto locked out hundreds of these unionists and replaced them with others, often less skilled, who were glad to find almost any job. But unlike so many others, then and now, who found their jobs stolen or abolished by global production shifts, these Boron workers were not alone. They had prepared for the lockout in a collective fashion, with meetings, strategy sessions, and on-the-job slowdowns and stoppages. The ILWU sent in food caravans, organized demonstrations, and enlisted friendly politicians to put pressure on Rico Tinto. They attended rallies in which prominent labor leaders attacked the global elite, but these workers could also speak for themselves. Their fight was in the news on almost a daily basis and they had their own trusted spokesmen and women who put forth an ideologically and political coherent defense of their cause (Olney P., 2011).

At Boron the ILWU won, maintaining key seniority rights, wage standards, and union strength; at Longview the union reached a far less satisfactory agreement. But regardless of the outcome, we can see why "populist" would indeed serve as such a poor label if applied to their struggle. Many of the workers, especially in heavily Mormon Boron, were Republicans, later Trump Republicans, ${ }^{4}$ but their anti-corporate fight was of a far more concrete, programmatic, and efficacious sort than that rhetorically offered by the politicians labeled populist during the 2016 campaign season.

This same dichotomy would appear during the teacher strikes of 2018 and 2019. Liberal politicians of every sort, including presidential aspirants Bernie Sanders, Elizabeth Warren, and Kamala Harris, and leading Congressional liberals Alexandria OcasioCortez, Ted Lieu, and Adam Schiff rushed to offer support, but while these officeholders are sometimes labeled populists or their programs populist, few pundits or journalists made the mistake of labelling the school teachers themselves "populists". ${ }^{5}$ Their movement was too programmatic, too rooted in community, and too genuinely democratic for that label to apply. ${ }^{6}$ 
distinction between populism and the union impulse can also be found in American journalism. Although causality cannot be proved, the deployment of the words "organized labor" and "populism" in print media usage has been inversely linked during the last hundred and fifty years. In The New York Times, for example, reporters rarely used the word populist or populism during the era, 1910 through 1970, when the trade union idea was ascendant or when those institutions wielded great economic power. But as the unions declined and ceased to poise even much of a verbal challenge to existing corporate or governmental elites, populism rose to prominence as a descriptive label for working class or insurgent sentiment. By the year 2015 the word "populism" was used twice as much as the phrase "organized labor," an absolute reversal of the relationship 30 and more years before. ${ }^{7}$

21 Although a world of political, cultural, and moral difference divided Donald Trump and his supporters from the movement engendered by Bernie Sanders, the two did have this in common: during the 2016 campaign season both appealed to an alienated mass of white men and women who had little direct contact with organized politics or selfconscious interest groups. In both instances the enemy was a distant elite, in one instance the "billionaire class," in another craven Washington politicians or foreign trading powers. Trump's dystopian and conspiratorial world view, as well as that of his supporters, has been much debated, but for the purposes of this essay, an examination of left-wing populism might well be more important.

The 21st century populist revival tracks well to the right, but there are leftwing variants as well, in the U.S. most notably Occupy Wall Street and the 2016 Bernie Sanders campaign. Both are properly labeled "populist." The Sanders achievement was remarkable, perhaps even unprecedented in American presidential politics. Starting as a mere protest candidate, the Sanders candidacy quickly transcended the marginality into which it had been cast by all credentialed observers. Not only did he best the Clinton establishment machine in 22 states and win just over $45 \%$ of all Democratic Party primary votes cast in the Winter and Spring of 2016, but Sanders won more support than Clinton from down scale Democrats, an especially amazing development when one considers that most African-Americans, who broke decisively for Clinton, have incomes lower than the norm among Democratic Primary voters. His voters were also of a lower income than those of Trump (Silver N., 2016). Unlike the higher income, white liberal "wine track" insurgents like Howard Dean in 2004, Bill Bradley in 2000, Edward Kennedy in 1980, and even Barack Obama in 2008, Sanders captured, on a decidedly leftwing program, more white working-class votes than the woman who had long been anointed by virtually every Democratic Party leader and institution as their presumptive presidential candidate. His campaign built a mass constituency, pushed Hillary Clinton to the left, and energized a new generation of young voters.

But what was the content of his program and did it have a populist appeal? Sanders called himself a socialist and argued for a "political revolution." The fact that millions of people were willing to vote for a self-described socialist generations after Eugene V. Debs and Norman Thomas campaigned for the presidency is a remarkable testimony to the fading away of an older, Cold War inspired, taboo. And the deployment of the phrase "political revolution," offers a bracing contrast to Barrack Obama's flaccid invocation of the word "change" in the 2008 campaign. But regardless of such linguistic labeling, what in fact was the political content of this Sanders' populism? 

Sanders and his supporters hope to construct. Discourse centering upon the $99 \%$ has far more of a populist than a social democratic or trade union flavor. The problem is threefold: first, who are the $99 \%$ and are they likely to have anything in common with 
each other? Individuals making less than $\$ 480,930$ in 2016 were part of the $99 \%$ and so too are those on food stamps. ${ }^{8}$ They don't have much in common; indeed, their interests are likely to be in opposition. Nor does it help all that much to conflate the 99\% with the "middle class" whose upper reaches would thereby extend well into the ranks of elite professionals and various managers. To champion the $99 \%$ is to seek agency where none can be found. This is not a social category that can be mobilized. It is a statistical construct. One does not have to be a Marxist to recognize that class is not defined by income, consumption, or even education, but by the power and autonomy or the lack thereof - which people who sell their labor for their wages experience in daily life. Most members of what we, today, call the middle class do that as well.

Second, when we focus on this overbroad definition of a middle class as an object of concern, we are necessarily marginalizing, neglecting, and denigrating those who fall below it: those out of the workforce, those chronically unemployed, those on welfare, those whose aspirations are not middle class at all. As Michael Zweig has pointed out in The Working Class Majority: America's Best Kept Secret, when the working class disappears into an amorphous middle class, the working poor - a mere forty-six million strong - drops out of the picture. From Nixon to Trump, the American right has championed the middle class, often given a political twist by labeling it "the silent majority" or "the moral majority" precisely in order to denigrate low-income people of color and their liberal or radical partisans. Should the left be doing this as well? (Zweig M., 2000). ${ }^{9}$

30 And finally, it is important to understand what is wrong with a simple demonization of the $1 \%$. That is a politically imprecise category as well. Most in that $1 \%$ may be politically conservative and economically self-serving, while a prominent minority are civic-minded liberals. But that is beside the point: the political significance of the $1 \%$ or as Paul Krugman and others point out, the $.01 \%$ - is that these people comprise an active group of capitalists whose overweening power over central economic and political institutions is both the cause of our difficulties and the proper target of all those who work for them, either directly in the corporations they control or in a public sector starved by virtue of the political and financial power wielded by that same elite stratum (Krugman P., 2019, A24). Taxing away their income by half would certainly free up money for schools, infrastructure, health care and the like, but it would do little to limit their power.

31 During the Great Depression, income inequality reached record lows, if only because the value of the stocks and real estate held by the $1 \%$ of that era declined in precipitous fashion. But we do not remember the New Deal for that. Instead, the Roosevelt Administration and the social movements that sustained it remain a hallmark of progressive statecraft because it helped shift the structure of social and economic power. In the 1930s FDR gave many speeches that today we might easily label as populist. In his famous address to the 1936 Democratic convention, for example, Roosevelt denounced the "economic royalists" who had "carved new dynasties" based upon their command of the giant corporations and powerful banks that emerged in the 20th century. He denounced "the privileged princes of these new economic dynasties, thirsting for power, (who) reached out for control over Government itself. They created a new despotism and wrapped it in the robes of legal sanction." 10 Truman, Stevenson, Kennedy and Johnson, never offered such red meat to the 
Democratic Party base. But FDR's "populism" - and no observer then or later would ever think of labeling his rhetoric with that word - had a multigenerational longevity because it was backstopped, not only by new governmental laws and regulations, such as the Securities and Exchange Commission or the Fair Labor Standards Act, but by the creation of institutions, most notably the powerful industrial unions, which organized millions of employees who worked for corporations that stood at the commanding heights of the national economy. These unions were mobilizing institutions whose very existence was predicated upon a constant battle to limit the prerogatives of capital and enhance the living standards of all those who exchanged labor for bread and shelter. Thus, was populist rhetoric transformed into a social democratic political culture.

Some old ideas remain valid and potent. For two centuries the rise of an organized working class in the West has coincided with the advance of a democratic polity. Conversely, the demise of contemporary U.S. unionism - it now stands at about six percent in the private sector - means that not only is it much more difficult to raise living standards, but that politics moves in an oligarchic and rightwing direction. The industrial Midwest has swung toward the GOP during the last several years not because there is anything inherently rightwing about a population that is more white, blue collar, and high school educated than in other states, but because the humbling of the union movement in Michigan, Ohio, Indiana, Iowa, Wisconsin and West Virginia has gravely weakened a set of institutions that sustained Democratic Party strength and social democratic values. In their place the door opens wide to resentment, resignation, and atavistic, and authoritarian political leadership.

Thus, we have witnessed the dramatic transformation of West Virginia from a bulwark of Rooseveltian liberalism and working-class militancy to a right-to-work state of ruby red coloration. This shift was closely linked not just to the demise of its historic industries, but to the pulverization of a unionized workforce schooled by home grown leaders seeking collective solutions to pressing social and economic problems. Union density in West Virginia declined from above 30 percent in the early 1980s to about 12 percent today, one of the sharpest drops of any state. Unemployment in the state remains generally higher than the national average, but the larger problem is the substitution of low-wage, non-union service sector jobs for those of a much higherpaying and dignified character. Mining and manufacturing employment dropped precipitously from the late 1980s until today, while retail and service sector jobs offered a statistical, if not a substantive, replacement. Walmart, for example, is the state's largest private sector employer, with almost 12,500 workers, about the same as all the coal companies combined (American Friends Service Committee, 2013). ${ }^{11}$

But it is not just a question of low wages. In his important book, What Unions No Longer Do, Jake Rosenfeld makes the case that the decline of unionism is responsible for about one third of the overall increase in U.S. wage inequality among men and about one fifth among women. But even more important, the near absence of unionism among workers who stand in the bottom half of the private sector workforce has proven disastrous for political participation within this stratum (Rosenfeld J., 2014). Union members are at least 20 percent more likely to vote in presidential elections than nonmembers and they are 43 percent more likely to volunteer in such a campaign. Other studies have shown that if all other variables are held constant, a unionized worker is about 15 percent more likely to vote Democratic than one not in a union. And as Judith Stein pointed out just before the 2016 election, there are just two places 
where working class people, regardless of race, can get leadership skills in America: the union and the church (Stein J., 2016). Both privilege loyalty, self-education, and organic leadership over formal credentials earned elsewhere. The latter flourishes and tilts right, certainly in its evangelical, mega-church version. The unions are having a harder time, if only because their very existence is demonized and resisted by a huge majority of all employers, both public as well as private.

Policy initiatives like the "Fight for $\$ 15$ " that seek to raise wages and thereby reduce income inequality are a good thing and widely popular in the contemporary U.S. But such otherwise salutary campaigns for an improvement of U.S. labor standards - which include sick leave, regular shifts, overtime pay, increases in the minimum wage - often implemented through referenda, executive orders, and new ordnances and legislation are not a substitute for the revival of trade unionism. Without a revival of this bedrock working-class institution, redistributive tax policy and progressive welfare programs will always remain on shaky ground.

Trade unions crystalize and institutionalize working-class sentiment and militancy. Consciousness is episodic, public opinion and political commitments come and go, so without an organization that includes a paid staff, recognized leadership, and steady income, employers and their political allies know that they just have to wait a few years for the energy and commitment of a movement like "The Fight for \$15" to drain away, after which inflation, technological change, and shifting consumption patterns will all erode these social movement achievements. Conversely, the existence of a union, in virtually any form or coloration, constitutes an institutional expression of the elevated consciousness of those who in a moment of engagement actually mobilized their workmates and built an organization to permanently represent that new ideological and social understanding. Member dues pay for a staff whose task it is to continually mobilize the membership, recruit new ones, and confront employer and state opponents. If this appears to be an argument for bureaucracy and against spontaneity, populist or otherwise, the reader is correct. ${ }^{12}$

In the absence of a union revival - or really of any kind of progressive organization or party that gives coherence to working-class fears and aspirations - we are condemned to watch populist history repeat itself. On the left, tribunes like Sanders, and before him John Edwards, Howard Dean, Ralph Nader, and Jesse Jackson will come and go. Meanwhile, on the right, populism of a far more retrograde sort makes steady headway within an unorganized and increasingly alienated white working-class that in better days gave its allegiance to a New Deal liberalism that stretched well into the postwar era. These populisms, both on the left and the right, flourish in an episodic fashion today because they are neither true protest movements, like that of civil rights and feminism in their heyday, nor based upon political and social institutions that can exist independent of the feverish campaign season. Not surprisingly, when unions and union-oriented Democrats were stronger in America, such populist impulses found little purchase within the body politic. Should the labor movement stir again, inspiring and channeling the social energy and anti-elite grievance so prevalent in our time, such populisms will rapidly fade, and a good thing too. 


\section{BIBLIOGRAPHY}

American Friends Service Committee, The State of Working West Virginia: from Weirton Steel to Wal-Mart, Charlestown, West Virginia, Center on Budget and Policy, 2013.

Bell, Daniel, ed., The Radical Right: The New American Right Expanded and Updated, New York: Anchor Books, 1964.

Blanc, Eric, Red State Revolt: The Teachers' Strike Wave and Working-Class Politics, New York: Verso, 2019.

Bonikowski, Bert, and Noam Gidron, “Trump and Sanders aren't Blazing New Trails. Populist $\mathrm{h}$ as Run Through U.S. Politics for a Very Long Time,” Washington Post, April 25, 2016.

Brown, David W., “Obama's Missed Opportunities with Organizing for America," Washington Post, April 5, 2012.

Bryant, Jeff, "West Virginia Teachers Tell Us Why Public Schools and Unions Matter," Commondreams.org, March 11, 2018.

Denison, Dave, “Perot: New Style Populist?” Baltimore Sun, June 28, 1992.

Dovere, Edward Isaac, “Bernie’s Army in Disarray,” Politico, May 21, 2018.

Goldberg, Jonah, "Trump and Sanders Break the Mold for Populist Politicians, National Review, December 30, 2015.

Greenhouse, Steven, “Union Dispute, Turning Violent, Spreads and Idles Ports”, New York Times, September 9, 2011, B2.

Hofstadter, Richard, The Age of Reform, New York, Random House, 1955.

Hofstadter, Richard, Anti-Intellectualism in American Life, New York: Random House, 1963.

Judis, John, The Populist Explosion: How the Great Recession Transformed American and European Politics, New York: Columbia Global Reports, 2016.

Kazin, Michael, The Populist Persuasion: An American History, New York: Basic Books, 1995.

Krugman, Paul, "Bernie Sanders and the Myth of the 1 Percent," The New York Times, April 18, 2019, A 24.

Jones, Sarah, “Is It Time for Change at Our Revolution? The New Republic on-line, 22 mai 2018.

Lichtenstein, Nelson, "West Virginia Teachers Tell Us Why Public Schools and Unions Matter," Commondreams.org, March 11, 2018.

Muller, Jan-Werner, “How Can Populism Be Defeated?" in Michael Ignatieff and Stefan Roch, dirs., Rethinking Open Society, Budapest, Central European University Press, 2018.

Muller, Jan-Werner, What is Populism? New York, Random House, 2017.

Muncy, Robyn, "The Strange Career of "the Working Class" in US Political Culture since the 1950s," LABOR: Studies in Working-Class History, vol. 15, nº 4 Decembre 2018

Nugent, Walter T.K., The Tolerant Populists: Kansas Populism and Nativism, Chicago, University of Chicago Press, 1963.

Olney, Peter, "Battle in the Mojave: Lessons from the Rio Tinto Lockout," New Labor Forum, 4 Mars 2011. 
Phillips, Cabell, "Space Age Populists: Senate Test Today on Satellite Bill Recalls Political Fires of the 1890s." New York Times, 14 aout 1962.

Postel, Charles, The Populist Vision, New York, Oxford University Press, 2007.

Rogin, Michael, The Intellectuals and McCarthy: the Radical Specter, Cambridge, MIT Press, 1967.

Rosenfeld, Jake, What Unions No Longer Do, Cambridge, Harvard University Press, 2014

Silver, Nate, “The Mythology of Trump's ‘Working Class' Support,” New York Times, 3 mai 2016.

Sonti, Samir, « LA Teachers Show the Way Forward », Jacobin on-line, 4 février 2019.

Stein, Judith, "Why Did White Workers Leave the Democratic Party," Jacobin, 20 juin, 2016

Zweig, Michael, The Working Class Majority: America's Best Kept Secret, Ithaca, Cornell UP, 2000

\section{NOTES}

1. "Drawing the Line Against Corporate Greed in Boron," ILWU Dispatcher, March 2011.

2. Bob Young, "In Cowiltz County, Blue-Collar Men See Economy - and Votes - Shifting," Seattle Times, September 1, 2016, 1: Kern County and the relevant Boron precincts voted for Trump in 2016, Kern County Elections web page.

3. Ralph Chaplin wrote the lyrics of "Solidarity Forever" in 1915 for the socialist/syndicalist Industrial Workers of the World. It is sung to the tune of "John Brown's Body."

4. Peter Olney e-mail to author, September 5, 2016. Olney was a former staffer with the ILWU.

5. Daniel Marans and Sarah Ruiz-Grossman, "These Are the Democrats Supporting the LA Teacher Strike," Huffington Post, January 15, 2019; and during the 2016 presidential primaries Bernie Sanders joined a picket line of striking Verizon workers. Dave Jamieson, "Bernie Sanders Joins Verizon Workers on Picket Line," Huffington Post, April 14, 2016. Hillary Clinton also showed up at a strike support event for those telephone workers.

6. The strike of Los Angeles teachers, well organized into the United Teachers of Los Angeles, received extensive media coverage in California and nationally. Few reporters or pundits used the word "populist" to describe it. See for example, Dakota Smith, "How L.A. Teachers Scored a Decisive Political Victory with Strike," Los Angeles Times, January 23, 2019, 1.

7. http://chronicle.nytlabs.com/?keyword=trade\%20unions.populist\&format=count; and see also (Muncy R., 2018, 37-58).

8. Aimee Picchi, "How Much Do the 1, .01 and .001 Percent Really Earn?" CBS Moneywatch, February 27, 2018; and see also, "The Top 1 Percent," The Tax Foundation on-line.

9. A longer discussion of the mistaken use of the term "middle class" can be found in Nelson Lichtenstein, “Class Unconsciousness: Stop Using 'Middle Class' to Depict the Labor Movement," New Labor Forum, 21(2), Spring 2012, 10-13.

10. "Acceptance Speech for the Renomination for the Presidency," Philadelphia, June 27, 1936 at The American Presidency Project, on-line

11. Wal-Mart, Inc. web site offers state by state employment statistics.

12. The Service Employees International Union funded the $\$ 15$ minimum wage struggle in many cities. 


\section{ABSTRACTS}

If in contemporary parlance "populism" stands for a social or political movement embodying otherwise unorganized and atomized anti-elite sentiment, then trade unionism is not populist. Labor organizations are anti-elitist, but they have a concrete program, a sense of social solidarity, a reasonably democratic leadership structure, and the capacity to exist once the fever or the election season has passed. Little of this is true of political campaigns and social insurgencies, including those of Bernie Sanders and Donald Trump, which have played such a prominent role in recent American life. A survey of some recent U.S. strikes, including those of blue-collar whites in heavy industry and white-collar teachers of multicultural hue, demonstrates the validity of this thesis.

$\mathrm{Si}$, dans le langage contemporain, le « populisme » représente un mouvement social ou politique qui incarne un sentiment anti-élite non organisé et atomisé, alors le syndicalisme n'est pas populiste. Les organisations syndicales sont anti-élitistes, mais elles ont un programme concret, un sens de la solidarité sociale, une structure de leadership raisonnablement démocratique et la capacité d'exister une fois la fièvre ou la saison électorale passée. Cela ne vaut guère pour les campagnes politiques et les insurrections sociales, y compris celles de Bernie Sanders et de Donald Trump, qui ont joué un rôle si important dans la vie américaine récente. Un survol de certaines grèves récentes aux États-Unis, y compris celles des cols bleus de l'industrie lourde et des enseignants cols blancs de couleur multiculturelle, démontre la validité de cette thèse.

Si en el lenguaje contemporáneo el "populismo" representa un movimiento social o político que encarna un sentimiento antielite no organizado y atomizado, entonces el sindicalismo no es populista. Las organizaciones sindicales son antielitistas, pero tienen un programa concreto, un sentido de solidaridad social, una estructura de liderazgo razonablemente democrática y la capacidad de existir una vez que haya pasado la fiebre o la temporada electoral. Poco de esto se aplica a las campañas políticas y a las insurgencias sociales, incluidas las de Bernie Sanders y Donald Trump, que han desempeñado un papel tan prominente en la vida estadounidense reciente. Una encuesta de algunas huelgas recientes en Estados Unidos, incluyendo las de los blancos obreros en la industria pesada y las de los maestros obreros de tono multicultural, demuestra la validez de esta tesis.

\section{INDEX}

Palabras claves: populismo, trabajo, huelgas, sindicatos, Sanders, Trump

Keywords: populism, labor, strikes, unions, Sanders, Trump

Mots-clés: populisme, travail, grèves, syndicats, Sanders, Trump

\section{AUTHOR}

\section{NELSON LICHTENSTEIN}

Nelson Lichtenstein is Distinguished Professor of History at the University of California, Santa Barbara where he directs the Center for the Study of Work, Labor, and Democracy. He is the author, most recently, of A Contest of Ideas: Capital, Politics, and Labor (2013); The Retail Revolution: How Wal-Mart Created a Brave New World of Business (2010); and the co-editor of The Right and Labor 
in America: Politics, Ideology, and Imagination (2015); and Beyond the New Deal Order (2019). His e-mail is nelson@history.ucsb.edu 